Article

\title{
The Effects of Code-Switching and Lexical Stress on Vowel Quality and Duration of Heritage Speakers of Spanish
}

\author{
Vanessa Elias *, Sean McKinnon (D) and Ángel Milla-Muñoz \\ Department of Spanish and Portuguese, Indiana University, 355 North Jordan Avenue, GISB 2160, Bloomington, \\ IN 47405, USA; samckinn@indiana.edu (S.M.); amilla@indiana.edu (A.M.-M.) \\ * Correspondence: mavelias@indiana.edu
}

Academic Editors: Antje Muntendam and Carolina González

Received: 30 June 2017; Accepted: 12 December 2017; Published: 21 December 2017

\begin{abstract}
The quantity of research on Heritage Speakers (HS) of Spanish phonetics has increased over the last decade, including studies on the possible effect of code-switching on Spanish phonetics. Following this line of research, the present study investigates the role of code-switching and lexical stress on Spanish HS vowel production, specifically if the introduction of English reduces the vowel quality and duration of Spanish vowels after a code-switch. Eleven Spanish HSs participated in a controlled narration task in which they were asked to read aloud texts that code-switched between English and Spanish and one text that only contained Spanish. PRAAT was used to segment the vowels and the F1 and F2 values, along with duration, were extracted. The results show that both code-switching and lexical stress significantly affect Spanish HS vowels. Code-switching and vowels in unstressed position were more centralized than the vowels in the monolingual Spanish session and vowels in stressed position, respectively; unstressed vowels were also shorter in duration than stressed vowels. These results show that the introduction of English-a language in which vowel quality and duration change between unstressed and stressed syllables-via code-switching significantly affects Spanish HS vowels, subsequently providing evidence for transient interference.
\end{abstract}

Keywords: Spanish heritage speakers; phonetics; vowel production; code-switching; vowel quality; vowel duration; lexical stress

\section{Introduction}

Within the tradition of Hispanic linguistics, the quantity of research on heritage speakers (HSs) of Spanish has expanded over the past few decades, as can be seen from the increase in edited volumes [1-7] and state-of-the-art review articles [8-15] on the subject. Although the quantity of research on this population has increased, Rao and Ronquest point out that the majority of the research has focused on morphosyntax and pedagogy, while phonetics and phonology have received less attention in the literature [14]. Therefore, the present study seeks to expand our knowledge of Spanish HS phonetics and phonology by investigating the role that code-switching and lexical stress play on Spanish HS vowel production, particularly if simultaneous activation of English and Spanish reduces the vowel quality and duration of Spanish vowels. While previous studies have found a significant effect of lexical stress on Spanish HS vowel quality and duration [16], code-switching has not been examined within this particular area.

One commonly used definition of a heritage speaker is an individual "who is raised in a home where a non-English language is spoken. The student may speak or merely understand the heritage language and be, to some degree, bilingual in English and the heritage language" [17] (p. 1). An individual within this population is characterized by having early exposure to the heritage language 
(HL), which, in the case of the present study, is Spanish. However, research has shown that Spanish HSs typically only receive HL input in familiar contexts, meaning that they often receive little formal education in the HL [18-20]; consequently, many Spanish HSs are dominant in Spanish at a young age, but shift to English-language dominance as they get older, due to their increased use of English once they enter the education system $[20,21]$. This exposure to Spanish at home and lack of formal education in the HL typically results in advanced oral and comprehension skills, and variable abilities in formal and written registers. However, this is not the case for proficiency in English, as Spanish HSs tend to use English in academic, social, and workplace settings, leading to more advanced and consistent skills in the majority language [18].

One major line of research in HL phonology has been to investigate whether or not HSs have a similar phonological system to their monolingual counterparts and/or second language (L2) learners, with respect to production. ${ }^{1}$ For example, early studies on Spanish HS [25-27] and Korean HS [28] found differences between monolingual speakers, HSs, and L2 learners in their phonetic productions; furthermore, these studies found differences within the HS population, in that childhood speakers outperformed childhood overhearers. ${ }^{2}$ Hrycyna et al. [29] also showed differences between two HL populations (i.e., Russian and Ukrainian) living in Toronto and their monolingual counterparts by showing that these participants had longer voice onset time (VOT) values, presumably due to contact with English, which has long-lag VOT values for its voiceless stops. Additionally, Godson demonstrated how English affected the vocalic system of Western Armenian HSs [30]. Finally, Saadah's investigation of short and long vowels in monolingual Arabic speakers, Arabic HSs, and L2 learners found that the HSs presented patterns more similar to L2 learners with the vowel / $\mathrm{u}$ :/, and while they differed from both monolingual Arabic speakers and L2 learners with /a, a:, u/ [31].

Although several studies have found differences between HSs and monolingual speakers, as well as with L2 learners, other studies have found that HSs may not be different from monolingual speakers. For example, the Italian HS group in Hrycyna et al. did not produce long-lag VOT values, which led the authors to speculate that the cohesiveness of the heritage communities and opportunities to speak the HL outside of the home may account for the variation in VOT values across the three languages [29]. Additionally, Saadah found that the Arabic HSs were similar to monolingual Arabic speakers with respect to the high fronted vowels /i, i:/ [31]. Finally, Chang et al.'s study of monolingual Mandarin and Mandarin HSs also found that their HS group maintained phonemic contrasts in Mandarin, and also differentiated between several similar English and Mandarin sounds (i.e., back vowels, stops, and fricatives) [32]. Therefore, while some studies show that HSs may be different from their monolingual counterparts [25-29,31], other studies have shown that HSs are able to acquire and maintain the phonological systems of both of their languages [29,31,32].

With respect to the phonological segment under investigation in the present study, i.e., Spanish vowels, Willis first noted that Southwest HS vowels might differ from the monolingual norms [33], given that he found fronted productions of $/ \mathrm{a} /$, lowered productions of $/ \mathrm{o} /$, and both fronted and lowered productions of $/ \mathrm{u} /$, when compared to monolingual values from Quilis and Esgueva [34]. More recently, Ronquest examined the role that lexical stress plays in the vowel quality and duration of vowels in the Spanish of HSs from Chicago [16]. The results of the study demonstrated that all the vowels, except /a/, exhibited significant centralization of the vowel space when in atonic position; moreover, atonic vowels were significantly shorter in duration than tonic vowels. Both of these results

1 While there are studies that have examined HS perception [22,23] and perception of "foreign accent" with HS populations [24], our discussion of previous HL phonological studies will be limited to production given that the focus of the present paper is on the production of Spanish HS vowels.

2 Au et al. [27] defined childhood speakers as individuals who spoke Spanish regularly for at least three years before the age of six. After the age of six, they continued to speak Spanish, but with less frequency than before. For childhood overhearers, $\mathrm{Au}$ et al. defined them as individuals who overheard spoken Spanish for several hours each week for a minimum of three years before the age of six [25]. However, they did not speak the language and received less Spanish input after the age of six. 
suggest that Spanish HS atonic vowels might involve a higher degree of reduction than those of monolingual Spanish speakers [34,35]. Additionally, Alvord and Rogers also found centralization of all vowels, except $/ \mathrm{u} /$, for all their Cuban participants residing in Miami [36], which ranged from first-generation immigrants to third-generation immigrants according to Silva-Corvalán's [37] categorization. ${ }^{3}$ The authors argue that, despite observing movement towards the center of the vowel space, this was not due to English influence, given that none of the participants, with the exception of one, produced any full schwas in unstressed position.

While these studies focused on Spanish HSs' productions in Spanish compared to monolingual Spanish speakers, i.e., a between-subjects design, it is also possible to examine participants' language productions in two distinct situations, i.e., a within-subjects design. One framework to investigate the latter is Grosjean's [38] bilingual language modes framework. This framework argues that there are two possible types of influence from one language on the other: transfer (i.e., "permanent, or relatively permanent, traces of one language on the other" (p. 13)) and interference (i.e., "ephemeral intrusions of the other language" (p. 13)). Both of these types of influence can be observed in monolingual mode (i.e., "[when bilinguals] are interacting only with (or listening only to) monolinguals of one- or the other-of the languages they know (p.12)") or bilingual mode (i.e., "[when bilinguals] are communicating with (or listening to) bilinguals who share their two (or more) languages and with whom code-switching and borrowing may take place" (p. 12)). Although Grosjean states that differentiating between these two types of influence will be difficult [38], given that they are similar to each other and can be found in both monolingual and bilingual mode, Simonet argues that interference, or what he calls "transient interference", should be more common in bilingual mode than in monolingual mode, since both languages are activated in bilingual mode [39]. As noted by Simonet, one way to induce bilingual mode in speech production is to have participants code-switch [39].

With respect to bilingual mode and phonetics, there are studies that have investigated the effects of Spanish-English code-switching on Spanish phonetics. For example, Bullock and Toribio [40] examined the VOT of English and Spanish voiceless stops with eight early Spanish-English bilinguals, ten L1 Spanish bilinguals, and fifteen L1 English bilinguals. The results demonstrated that, despite maintaining separate phonological systems, the early bilinguals' VOT values exhibited convergence in the direction of the opposite language; this is to say, when code-switching from Spanish to English, the early bilinguals had shorter English VOT values, while when code-switching from English to Spanish these participants had longer Spanish VOT values. While Bullock and Toribio found effects of code-switching on the voiceless stops after the code-switch [40], Balukas and Koops found an anticipatory effect when the bilinguals switched from Spanish to English [41]; their results showed reduced VOT values in the English tokens that were closer to the switch site, but they did not find the same effects for Spanish tokens. Piccinini and Arvaniti also found differences in VOT values between code-switching and monolingual sessions [42]. They found that the voiceless stops, both in English and in Spanish, in code-switching utterances had shorter VOT values before and after the switch than voiceless stops in monolingual English and in monolingual Spanish utterances. Despite the differences in these studies, especially regarding the placement of the token with respect to the code-switch, they highlight the possibility that code-switching can significantly affect the phonetic production of bilinguals.

Moving beyond segmental phonology, Olson examined the effect of code-switching on suprasegmental features, specifically on pitch height and on vowel duration [43]. The participants read aloud three different types of stimuli, one all in English, one all in Spanish, and one that code-switched from Spanish to English. Olson's study revealed a significant difference in pitch height between the two

3 Silva-Corvalán defines the first generation as individuals immigrated to the U.S. after the age of 11 [37]. The second generation are immigrants who came to the U.S. before the age of six or who were born in the U.S. to at least one first-generation parent. Third generation immigrants were born in the U.S. and have at least one parent from the second generation. 
monolingual sessions and the code-switching session, in that the code-switching session had higher pitch heights than both monolingual sessions [43]. For vowel duration, Olson examined the duration of English vowels in stressed position in the code-switching stimuli and compared them to vowels in both monolingual sessions. The results showed that vowels in the code-switching session were significantly longer than vowels produced in both monolingual sessions. Furthermore, a comparison of the code-switching vowels to the English-only session demonstrated that vowels in the code-switching session were on average 18\% longer than vowels in the English-only session. Olson's study provides further evidence that activation of both languages in a single utterance not only affects phonetic production at the segmental level, but also at the suprasegmental level [43].

As can be seen from previous studies on HL phonology and the effects code-switching, HS research has followed two data collection methods: assessing HS speakers while only one of their languages (i.e., their HL) is activated [16,25-31,36], or testing them while both of their languages are activated via code-switching [40-43]. As Simonet demonstrated, inducing a bilingual mode may cause transient interference of one language on the other when the productions from bilingual mode are compared to productions from monolingual mode [39]. Following this line of thought, the present study is interested in examining if there are transient effects of English, which will be activated via code-switching, on Spanish vowels that follow a code-switch within a sample of Midwestern U.S. heritage speakers of Spanish. We define potential transient effects of English in terms of changes in vowel quality and duration, i.e., vowel reduction; our study differs from previous research on Spanish HS vowels $[16,33,36]$ in that those studies only examined monolingual Spanish vowels, while the present study compares Spanish vowels produced in monolingual mode to Spanish vowels produced in a Spanish-English code-switching context (i.e., bilingual mode). Furthermore, we wish to explore the possibility that transient effects of English will be the strongest right after a code-switch, following previous findings for VOT [41,42]. In order to answer these questions, our study was guided by four research questions:

1. Is there an effect of code-switching and lexical stress on the vowel quality of heritage speakers of Spanish?

2. Is there an effect of code-switching and lexical stress on the vowel duration of heritage speakers of Spanish?

3. Is there an effect of distance from the code-switching site on the vowel quality of heritage speakers of Spanish?

4. Is there an effect of distance from the code-switching site on the vowel duration of heritage speakers of Spanish?

Following previous research [16], we hypothesize that lexically unstressed vowels will differ in both vowel quality and duration from their lexically stressed counterparts. Specifically unstressed vowels will be shorter in duration and be more centralized via changes in F1 and/or F2. With respect to the effect of code-switching, we predict that the introduction of English via code-switching will produce differences in Spanish vowels after a code-switch, in that they will be shorter in duration and more centralized than Spanish vowels produced in a monolingual Spanish mode; this is based on previous research that has shown that the introduction of English makes Spanish productions more English-like than monolingual Spanish phonetic productions [40,42]. Finally, we hypothesize that Spanish vowels closer to the code-switch site will exhibit more effects from English than vowels that are further away from the code-switching site, in light of the results of previous research [41,42]. Overall, we predict that our results will show that Spanish HS vowels are different from what has been reported for Spanish monolinguals [34,35], and will also support previous work on HL phonology [25-29,31] and research on transient phonetic interference in bilingual mode [39]. 


\section{Materials and Methods}

\subsection{Participants}

Eleven Spanish HSs, who were born and raised in the Midwestern region of the United States, participated in the present study; all participants gave their oral consent to participate in the study. There were eight females and three males, and all participants reported that their parents were born in Mexico. Their ages ranged from 18 to 20 years old (mean age: 18.5 years old). The participants were identified through the first author's personal contacts and they were all enrolled in Spanish courses at a large Midwestern university at the time of the study. Almost all participants self-reported having learned Spanish from birth (except for a participant who began learning Spanish at the age of four) and began to learn English at an early age (mean age for learning English: 1.8 years old). With the purpose of assessing their level of proficiency in Spanish, participants were requested to take a Spanish language exam, which reported the following results seen in Table 1 below. The maximum score for this test was 50 points. Following Montrul [44], we classified the participants into three levels of proficiency: advanced (scores from 40 to 50), intermediate (scores from 25 to 39), and low intermediate (scores from 12 to 24 ), although none of the participants fell into the low-intermediate category.

Table 1. Participants' scores on the proficiency test.

\begin{tabular}{ccc}
\hline Participant Number & Score & Level of Proficiency \\
\hline 1 & $46 / 50$ & Advanced \\
2 & $37 / 50$ & Intermediate \\
3 & $35 / 50$ & Intermediate \\
4 & $34 / 50$ & Intermediate \\
5 & $48 / 50$ & Advanced \\
6 & $43 / 50$ & Advanced \\
7 & $43 / 50$ & Advanced \\
8 & $25 / 50$ & Intermediate \\
9 & $44 / 50$ & Advanced \\
10 & $45 / 50$ & Advanced \\
11 & $41 / 50$ & Advanced \\
\hline
\end{tabular}

Given that there are various language attitudes surrounding code-switching practices [45], the researchers asked potential participants if they felt comfortable code-switching prior to participating in the study; all participants indicated that they were comfortable and that they used code-switching in their daily lives. Recruitment took place after the present study's materials and methods were reviewed and approved by the Institutional Review Board from a large Midwestern university, which assigned this project the following protocol number: \#1601427043.

\subsection{Experimental Design}

In the present study, participants were asked to complete three different tasks: (1) a controlled narration reading task; (2) a background questionnaire; and (3) and a language proficiency exam, i.e., Diploma de Español como Lengua Extranjera (DELE) [46]. The DELE has been shown to be an independent and reliable test to measure participants' proficiency in other studies that included groups of HSs [18,47-49]. Following Bullock and Toribio [40], the experiment took place over two different sessions that were separated by a few days in order to mitigate any possible carry-over effects from one task into another. During session A (i.e., the code-switching session), participants read aloud four stories (see Appendixs A-D) that contained code-switches, and participated in a sociolinguistic interview, which was not analyzed in this paper. In session B (i.e., the monolingual session), participants read aloud one story that was completely in Spanish, in addition to filling out a background questionnaire and the DELE. The story read in the monolingual session was El gato con botas (see Appendix E). In order to encourage participants to remain in the language mode of the 
session, we had two different researchers conduct each session: the code-switching session A was conducted by a Spanish HS researcher who was born in the United States and whose parents are from Mexico, whereas a Spanish dominant Spanish-English bilingual, who speaks Andalusian Spanish, conducted the monolingual session B. For session A, the researcher used code-switching with the participants during the task, although the instructions were only administered in English.

The controlled reading task in both the monolingual and code-switching sessions asked participants to read aloud popular children's stories that were adapted from Anderson [50]. There were four stories in the code-switching session that contained Spanish-English code-switches, both intra- and inter-sentential. Saville-Troike defined "inter-sentential switching" as "the change which occurs between sentences or speech acts", and "intra-sentential switching" as "the change which occurs within a single sentence" [51] (p. 50). A few sample code-switches from these stories are provided below.

1. Spanish to English intra-sentential code-switch: Había una vez una joven muy bella ('There once was a beautiful young woman') whose mother had died when she was very young.

2. English to Spanish intra-sentential code-switch: She spent toda la noche llorando ('the whole night crying').

3. Spanish to English inter-sentential code-switch: Te enseñaré cómo es mi vida en la ciudad ('I will show you how my life is like in the city'). No country squirrel could refuse the invitation.

4. Spanish to English inter-sentential code-switch: They called her Cinderella. Un día el Príncipe de aquel país anunció ... ('One day the Prince from that country announced ... ').

Although all these types of code-switches were included in the stories, only intra-sentential code-switches were included in the analysis, given that overly long pauses between code-switches might have reduced the level of English activation. Therefore, and since we only analyzed one sub-set of possible code-switches (i.e., English to Spanish intra-sentential code-switches), we modified the Spanish parts after the code-switch to ensure that there were enough vowels by lexical stress position for statistical analyses; no other phonetic context, except for lexical stress, was taken into consideration when modifying the texts. In the data analysis, we did not include any SpanishEnglish cognates, given that previous research has shown that phonetic productions of these words tend to be different from non-cognate words [52-54]. Finally, since Spanish-English code-switching is mostly an informal speech phenomenon for our target population, the Spanish HS researcher verified that all the code-switches were grammatical and would sound natural to our participants, as well as certified that vocabulary would be appropriate for the target population.

Given that many Spanish vowels would be present in the monolingual session, participants only read aloud one story during the second session. All five stories from the two sessions can be found in Appendixs A-E.

Participants were recorded in a sound-proof booth with a Shure SM7B microphone (Shure Incorporated, Niles, IL, US), which was used with a Cloud Microphones Cloudlifter CL-2 microphone activator (Cloud Microphones, Tucson, AZ, US). This was run into a Universal Audio Apollo interface (Universal Audio Incorporated, Scotts Valley, CA, US), and recorded in Pro Tools (Avid, Burlington, MA, US) with a sampling rate of $44.1 \mathrm{kHz}$ and bit depth of 16 bits.

\subsection{Data Analysis}

After data collection, we isolated the five Spanish vowels in PRAAT (Amsterdam, the Netherlands, v. 6.0.23). For the code-switching data, we labeled the first five vowels after each intra-sentential code-switch from English to Spanish $(/ \mathrm{a} /=489, / \mathrm{e} /=364, / \mathrm{i} /=194, / \mathrm{o} /=230, / \mathrm{u} /=218)$. For the monolingual session we labeled the first 20 tokens per vowel per lexical stress position (e.g., 20 tokens of /a/ in stressed position, 20 tokens of /a/ in unstressed position, and so on). This totaled up to 200 tokens altogether in this session. We did not label vowels that came from the following cases: definite articles, possessives, prepositions, conjunctions, vowels before a nasal, diphthongs, 
and reported speech. Vowels from these tokens were excluded from consideration due to possible effects from word frequency (i.e., definite articles, possessives, prepositions, conjunctions), articulatory effects from adjacent segment (i.e., vowels before a nasal, diphthongs), and performance effects such as changing one's voice (i.e., reported speech). Additionally, for the code-switching session we excluded all vowels after a code-switch that was preceded by a pause of over $900 \mathrm{~ms}$, following Goldrick et al. [55].

In total, we obtained 3589 tokens, of which 1495 were from the code-switching session and 2094 were from the monolingual session. Each token was coded in PRAAT according to participant, lexical item, DELE score, vowel phoneme (i.e., /i, e, a, o, u/), lexical stress position (i.e., stressed vs unstressed), language of the session (i.e., code-switching vs monolingual), and, in the case of the code-switching vowels, distance from the code-switching site (i.e., the time after the initial switch to the onset of the vowel, measured in $\mathrm{ms}$ ). A visual representation of how the distance from the code-switching site was measured can be found in Figure 1.

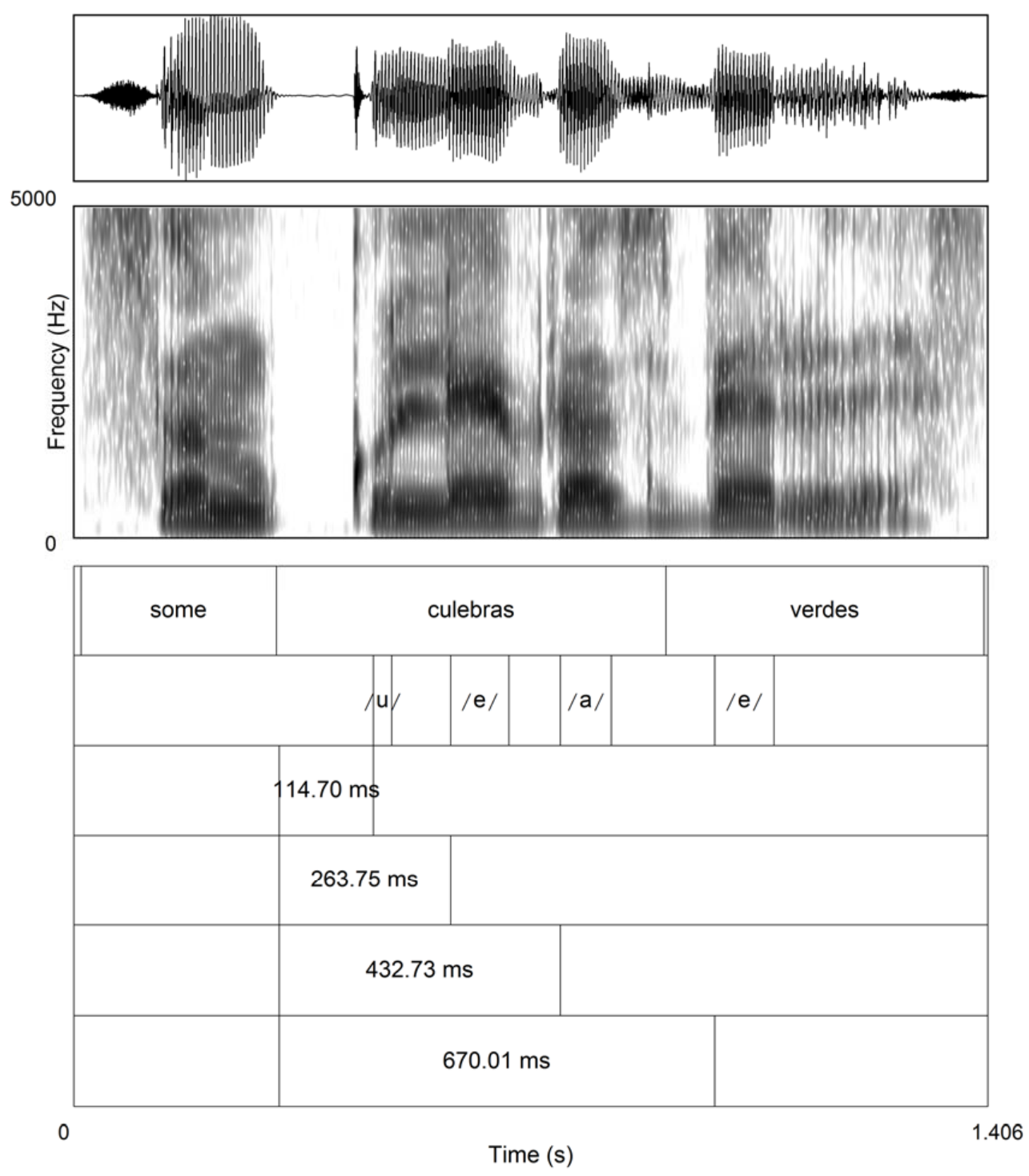

Figure 1. Example of how distance from the code-switching site was measured with the English-to-Spanish intra-sentential code-switch some culebras verdes 'some green snakes'.

Figure 1 analyzes the nominal phrase (NP) some culebras verdes 'some green snakes'. It shows a waveform and a spectrogram of the utterance followed by the tiers that measured the distance from 
the beginning of the code-switch from English to Spanish until the vowel token in question. To be more precise, Tier 1 displays the different words contained in the NP, Tier 2 shows the vowels we analyzed, and Tiers 3 through 6 delimit the distance from the end of the word in English until the beginning of the production of the vowel in Spanish.

After the tokens were labeled in PRAAT, a linear predictive coding (LPC) extracting algorithm was employed to extract the labeled vowels [56]. This same script was then used to take the F1 and F2 measurements at the midpoints of each vowel token, as well as extracting the duration of the vowel and the duration of the distance from the code-switch in the case of the code-switching vowels. Afterwards, the F1 and F2 measurements were normalized via the tool NORM (North Carolina State University, Raleigh, NC, USA, v.1.1.) using the Lobanov method [57] so as to minimize the physiological differences between biological sex in order to allow for the comparison of male and female data [58].

Regarding the quantitative analysis, we utilized a linear mixed effects model in SPSS (IBM, Armonk, NY, USA). Our dependent variables were the normalized F1 and F2 values, as well as vowel duration. Our independent variables were the vowel phonemes $(/ \mathrm{a}, \mathrm{e}, \mathrm{i}, \mathrm{o}, \mathrm{u} / \mathrm{)})$, lexical stress (i.e., stress or unstressed) and language session (i.e., monolingual or code-switching). We also included the individual participant and lexical item as random intercepts for the within-subject factors (i.e., our independent variables). Finally, we ran separate linear mixed effects models for all of the dependent variables with only the vowels from the code-switching session; for these models, the independent variables were the vowel phonemes, lexical stress and distance from the code-switching site (measured in $\mathrm{ms}$ ), and included participant and lexical item as random intercepts for the within-subject factors.

\section{Results}

The following section is divided according to the results of the linear mixed effects models for normalized F1/F2 values and vowel duration (Section 3.1), and of the linear mixed effects models for the code-switching subset of the data to examine the potential effect of distance from code-switching site and F1/F2 normalized values and vowel duration (Section 3.2).

\subsection{Normalized F1/F2 Values and Vowel Duration}

To begin this section, the F1 normalized results revealed that there was a main effect for vowel phoneme, $F(4,3584)=292.11, p<0.001$, lexical stress, $F(1,3587)=31.54, p<0.001$, and language session, $F(1,3587)=5.37, p=0.02$, but not for DELE, $F(1,3587)=0.58, p=0.45$. There were significant two-way interactions between vowel and lexical stress, $F(4,3584)=51.68, p<0.001$, and between vowel and language session, $F(4,3584)=6.20, p<0.001$. However, there was not a significant three-way interaction between vowel phoneme, lexical stress, and language session, $F(1,3583)=0.70, p=0.62$. Table 2 presents the mean values for the significant interactions, as well as the Cohen's $d$ effect size when the post-hoc analysis revealed significant pairwise differences between the mean values, while the estimates of the fixed effects from the linear mixed effects can be found in Table 3.

Table 2. Descriptive results for normalized F1 values.

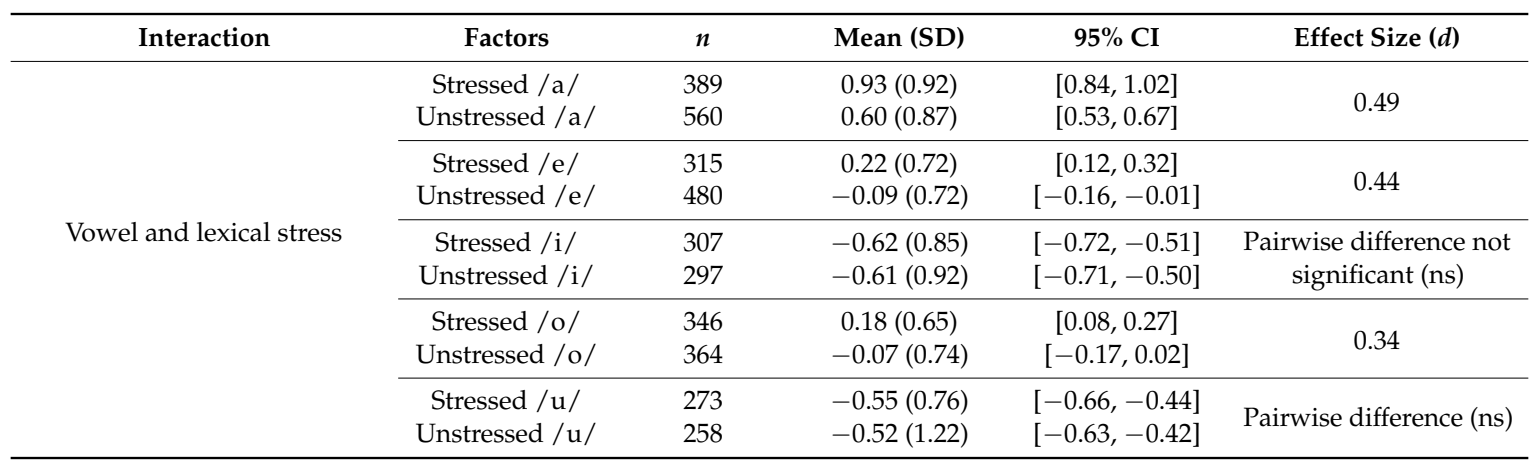


Table 2. Cont.

\begin{tabular}{|c|c|c|c|c|c|}
\hline Interaction & Factors & $n$ & Mean (SD) & $95 \%$ CI & Effect Size $(d)$ \\
\hline \multirow{5}{*}{$\begin{array}{l}\text { Vowel and language } \\
\text { session }\end{array}$} & $\begin{array}{l}\text { Code-switching /a/ } \\
\text { Monolingual /a/ }\end{array}$ & $\begin{array}{l}489 \\
460\end{array}$ & $\begin{array}{l}0.45(0.92) \\
1.08(0.78)\end{array}$ & $\begin{array}{l}{[0.37,0.54]} \\
{[1.00,1.16]}\end{array}$ & 0.77 \\
\hline & $\begin{array}{c}\text { Code-switching /e/ } \\
\text { Monolingual /e/ }\end{array}$ & $\begin{array}{l}364 \\
431\end{array}$ & $\begin{array}{l}0.04(0.82) \\
0.09(0.65)\end{array}$ & $\begin{array}{c}{[-0.06,0.13]} \\
{[0.02,0.18]}\end{array}$ & Pairwise difference (ns) \\
\hline & $\begin{array}{l}\text { Code-switching /i/ } \\
\text { Monolingual /i/ }\end{array}$ & $\begin{array}{l}194 \\
410\end{array}$ & $\begin{array}{l}-0.40(0.93) \\
-0.82(0.84)\end{array}$ & $\begin{array}{l}{[-0.52,-0.28]} \\
{[-0.91,-0.74]}\end{array}$ & 0.47 \\
\hline & $\begin{array}{l}\text { Code-switching /o/ } \\
\text { Monolingual /o/ }\end{array}$ & $\begin{array}{l}230 \\
480\end{array}$ & $\begin{array}{l}0.09(0.80) \\
0.01(0.65)\end{array}$ & $\begin{array}{l}{[-0.02,0.21]} \\
{[-0.07,0.09]}\end{array}$ & Pairwise difference (ns) \\
\hline & $\begin{array}{l}\text { Code-switching /u/ } \\
\text { Monolingual / u/ }\end{array}$ & $\begin{array}{l}218 \\
313\end{array}$ & $\begin{array}{l}-0.26(1.36) \\
-0.81(0.57)\end{array}$ & $\begin{array}{l}{[-0.38,-0.15]} \\
{[-0.90,-0.71]}\end{array}$ & 0.54 \\
\hline
\end{tabular}

CI: Confidence Intervals.

Table 3. Results from the linear mixed effects model for normalized F1 values.

\begin{tabular}{|c|c|c|c|c|c|}
\hline Parameter & Estimate & SE & df & $t$-Value & $p$-Value \\
\hline Intercept & -0.88 & 0.11 & 2099.12 & -8.19 & $<0.001$ \\
\hline Vowel = /a / & 2.10 & 0.09 & 590.99 & 23.97 & $<0.001$ \\
\hline Vowel $=/ \mathrm{e} /$ & 1.108 & 0.90 & 503.87 & 11.96 & $<0.001$ \\
\hline Vowel = /i/ & 0.03 & 0.09 & 493.32 & 0.33 & 0.74 \\
\hline Vowel = /o/ & 0.93 & 0.09 & 516.67 & 10.52 & $<0.001$ \\
\hline Lexical stress $=$ no & 0.03 & 0.10 & 738.25 & 0.30 & 0.76 \\
\hline Language session $=$ code-switching & 0.54 & 0.11 & 1096.64 & 5.15 & $<0.001$ \\
\hline DELE scores & 0.00 & 0.00 & 3469.39 & 0.76 & 0.45 \\
\hline Unstressed vowel = /a/ & -0.44 & 0.13 & 764.00 & -3.48 & 0.001 \\
\hline Unstressed vowel $=/ \mathrm{e} /$ & -0.34 & 0.13 & 718.3 & -2.71 & 0.007 \\
\hline Unstressed vowel $=/ \mathrm{i} /$ & -0.09 & 0.13 & 658.93 & -0.70 & 0.48 \\
\hline Unstressed vowel = /o/ & -0.23 & 0.13 & 670.20 & -1.85 & 0.064 \\
\hline Code-switching vowel = /a/ & -1.25 & 0.14 & 1056.46 & -9.07 & $<0.001$ \\
\hline Code-switching vowel = /e $/$ & -0.61 & 0.15 & 935.65 & -4.22 & $<0.001$ \\
\hline Code-switching vowel = /i/ & -0.19 & 0.15 & 918.87 & -1.28 & 0.20 \\
\hline Code-switching vowel $=/ \mathrm{o} /$ & -0.41 & 0.14 & 894.13 & -2.89 & 0.004 \\
\hline Code-switching, unstressed vowel $=/ \mathrm{a} /$ & 0.17 & 0.11 & 1670.30 & 1.48 & 0.14 \\
\hline Code-switching, unstressed vowel $=/ \mathrm{e} /$ & 0.02 & 0.13 & 938.54 & 0.18 & 0.86 \\
\hline Code-switching, unstressed vowel $=/ \mathrm{i}$ / & 0.14 & 0.15 & 1082.11 & 0.94 & 0.35 \\
\hline Code-switching, unstressed vowel $=/ \mathrm{o} /$ & -0.09 & 0.14 & 911.75 & -0.66 & 0.51 \\
\hline Code-switching, unstressed vowel $=/ \mathrm{u} /$ & 0.00 & 0.15 & 1066.28 & 0.02 & 0.98 \\
\hline
\end{tabular}

SE: Standard Error; df: degrees of freedom; DELE: Diploma de Español como Lengua Extranjera.

The results from Tables 2 and 3 show that for the interaction between vowel and lexical stress there were significant differences in the normalized $\mathrm{F} 1$ values for /a/, /e/, and /o/, in that vowels in lexically stressed syllables had higher F1 values (i.e., lower in the vowel space) than their lexically unstressed counterparts. With respect to the interaction between vowel and language session, the /a/ vowels in the monolingual session had statistically significantly higher F1 values than the /a/ vowels in the code-switching session, while the monolingual / $\mathrm{i} /$ and $/ \mathrm{u} /$ vowels had statistically significantly lower F1 values (i.e., higher in the vowel space) than the /i/ and / $\mathrm{u} /$ vowels in the code-switching session.

For the normalized F2 values, there was a main effect for vowel phoneme, $F(4,3584)=264.33$, $p<0.001$, but not for lexical stress, $F(1,3587)=2.98, p=0.08$, language session, $F(1,3587)=0.68$, $p=0.41$, or DELE, $F(1,3587)=0.39, p=0.53$. There were significant two-way interactions between vowel and lexical stress, $F(4,3584)=6.30, p<0.001$, and between vowel and language session, $F(4,3584)=43.02, p<0.001$. However, there was not a significant three-way interaction between vowel phoneme, lexical stress, and language session, $F(1,3583)=0.58, p=0.72$. 
The results from Tables 4 and 5 indicate that, for the interaction between vowel and lexical stress, there were statistically significant differences in the normalized F2 values for /e/, / / , /o/ and $/ \mathrm{u} /$, but that the direction of the differences was distinct: stressed /e/ and /i/ vowels had higher normalized F2 values (i.e., more fronted) than unstressed /e/ and /i/ tokens, while stressed /o/ and $/ \mathrm{u} /$ vowels had lower normalized F2 values (i.e., more back) than unstressed /o/ and / $\mathrm{u} /$ tokens. With respect to language session, monolingual /e/ and /i/ had higher normalized F2 values than their respective vowels in the code-switching session, while monolingual /o/ and / $\mathrm{u} / \mathrm{had}$ lower normalized F2 values than their code-switching counterparts.

Table 4. Descriptive results for normalized F2 values.

\begin{tabular}{|c|c|c|c|c|c|}
\hline Interaction & Factors & $n$ & Mean (SD) & $95 \%$ CI & Effect Size $(d)$ \\
\hline \multirow{10}{*}{$\begin{array}{c}\text { Vowel and lexical } \\
\text { stress }\end{array}$} & Stressed /a/ & 389 & $-0.10(0.55)$ & {$[-0.10,0.7]$} & Pairwise \\
\hline & Unstressed /a/ & 560 & $-0.01(0.68)$ & {$[-0.18,-0.02]$} & difference (ns) \\
\hline & Stressed /e/ & 315 & $0.33(0.67)$ & {$[-0.00,0.19]$} & Pairwise \\
\hline & Unstressed /e/ & 480 & $0.26(0.76)$ & {$[0.42,0.58]$} & difference (ns) \\
\hline & Stressed /i/ & 307 & $0.93(1.08)$ & {$[0.83,1.04]$} & \multirow{2}{*}{0.20} \\
\hline & Unstressed /i/ & 297 & $0.75(1.06)$ & {$[0.64,0.85]$} & \\
\hline & Stressed /o/ & 346 & $-0.70(0.74)$ & {$[-0.80,-0.60]$} & \multirow[b]{2}{*}{0.14} \\
\hline & Unstressed /o/ & 364 & $-0.58(0.79)$ & {$[-0.68,-0.48]$} & \\
\hline & Stressed /u/ & 273 & $-0.60(0.95)$ & {$[-0.71,-0.49]$} & \multirow{2}{*}{0.37} \\
\hline & Unstressed /u/ & 258 & $-0.30(0.93)$ & {$[-0.40,-0.19]$} & \\
\hline \multirow{10}{*}{$\begin{array}{c}\text { Vowel and } \\
\text { language session }\end{array}$} & Code-switching /a/ & 489 & $-0.02(0.73)$ & {$[-0.10,0.07]$} & Pairwise \\
\hline & Monolingual /a/ & 460 & $-0.10(0.51)$ & {$[-0.18,-0.12]$} & difference (ns) \\
\hline & Code-switching /e/ & 364 & $0.10(0.80)$ & {$[0.00,0.19]$} & \multirow{2}{*}{0.58} \\
\hline & Monolingual /e/ & 431 & $0.50(0.60)$ & {$[0.42,0.58]$} & \\
\hline & Code-switching /i/ & 194 & $0.54(1.06)$ & {$[0.41,0.66]$} & \multirow[b]{2}{*}{0.60} \\
\hline & Monolingual /i/ & 410 & $1.15(1.02)$ & {$[1.06,1.23]$} & \\
\hline & Code-switching /o/ & 230 & $-0.43(0.87)$ & {$[-0.54,-0.32]$} & \multirow[b]{2}{*}{0.55} \\
\hline & Monolingual /o/ & 480 & $-0.85(0.67)$ & {$[-0.93,-0.77]$} & \\
\hline & Code-switching / $\mathrm{u} /$ & 218 & $-0.26(1.03)$ & {$[-0.37,-0.14]$} & \multirow{2}{*}{0.42} \\
\hline & Monolingual /u/ & 313 & $-0.64(0.86)$ & {$[-0.74,-0.54]$} & \\
\hline
\end{tabular}

Table 5. Results from the linear mixed effects model for normalized F2 values.

\begin{tabular}{|c|c|c|c|c|c|}
\hline Parameter & Estimate & SE & df & $t$-Value & $p$-Value \\
\hline Intercept & -0.89 & 0.12 & 2127.50 & -8.27 & $<0.001$ \\
\hline Vowel = /a/ & 0.67 & 0.09 & 809.68 & 7.51 & $<0.001$ \\
\hline Vowel = /e / & 1.40 & 0.09 & 529.22 & 15.06 & $<0.001$ \\
\hline Vowel $=/ \mathrm{i} /$ & 2.09 & 0.09 & 643.01 & 22.47 & $<0.001$ \\
\hline Vowel = /o/ & -0.07 & 0.09 & 650.37 & -0.76 & 0.45 \\
\hline Lexical stress $=$ no & 0.39 & 0.10 & 812.09 & 3.97 & $<0.001$ \\
\hline Language session $=$ code-switching & 0.47 & 0.11 & 1220.00 & 4.41 & $<0.001$ \\
\hline DELE scores & 0.00 & 0.00 & 3439.15 & 0.625 & 0.532 \\
\hline Unstressed vowel = /a/ & -0.27 & 0.13 & 938.85 & -2.08 & 0.04 \\
\hline Unstressed vowel $=/ \mathrm{e} /$ & -0.52 & 0.13 & 767.08 & -4.00 & $<0.001$ \\
\hline Unstressed vowel = /i/ & -0.62 & 0.13 & 808.61 & -4.71 & $<0.001$ \\
\hline Unstressed vowel = /o/ & -0.28 & 0.13 & 837.56 & -2.23 & 0.03 \\
\hline Code-switching vowel $=/ \mathrm{a} /$ & -0.35 & 0.14 & 1316.06 & -2.52 & 0.01 \\
\hline Code-switching vowel $=/ \mathrm{e} /$ & -0.93 & 0.15 & 1050.23 & -6.33 & $<0.001$ \\
\hline Code-switching vowel = /i / & -1.12 & 0.14 & 1120.83 & -7.55 & $<0.001$ \\
\hline Code-switching vowel $=/ \mathrm{o} /$ & -0.06 & 0.14 & 1073.382 & -0.40 & 0.69 \\
\hline Code-switching, unstressed vowel = /a / & -0.07 & 0.11 & 2206.76 & -0.652 & 0.51 \\
\hline Code-switching, unstressed vowel = /e/ & 0.11 & 0.13 & 1042.46 & 0.92 & 0.36 \\
\hline Code-switching, unstressed vowel = /i/ & 0.08 & 0.15 & 1382.76 & 0.57 & 0.57 \\
\hline Code-switching, unstressed vowel $=/ \mathrm{o} /$ & 0.02 & 0.14 & 1173.25 & 0.15 & 0.88 \\
\hline Code-switching, unstressed vowel $=/ \mathrm{u} /$ & -0.17 & 0.15 & 1207.95 & -1.15 & 0.25 \\
\hline
\end{tabular}


To visually summarize the results in a meaningful way, Figure 2 presents a graphic representation of the differences between Spanish vowels in the monolingual (represented by circles) and code-switching (represented by triangles) sessions. Furthermore, each vowel is represented by its own color: blue $(/ \mathrm{a} /)$, yellow $(/ \mathrm{e} /)$, red $(/ \mathrm{i} /)$, purple $(/ \mathrm{o} /)$, and green $(/ \mathrm{u} /)$. Normalized $\mathrm{F} 1$ values (i.e., vowel height) are found on the $y$-axis and the normalized $F 2$ values (i.e., front/backness) are on the $x$-axis. Solid black lines connect the vowels to form the vocalic triangle.

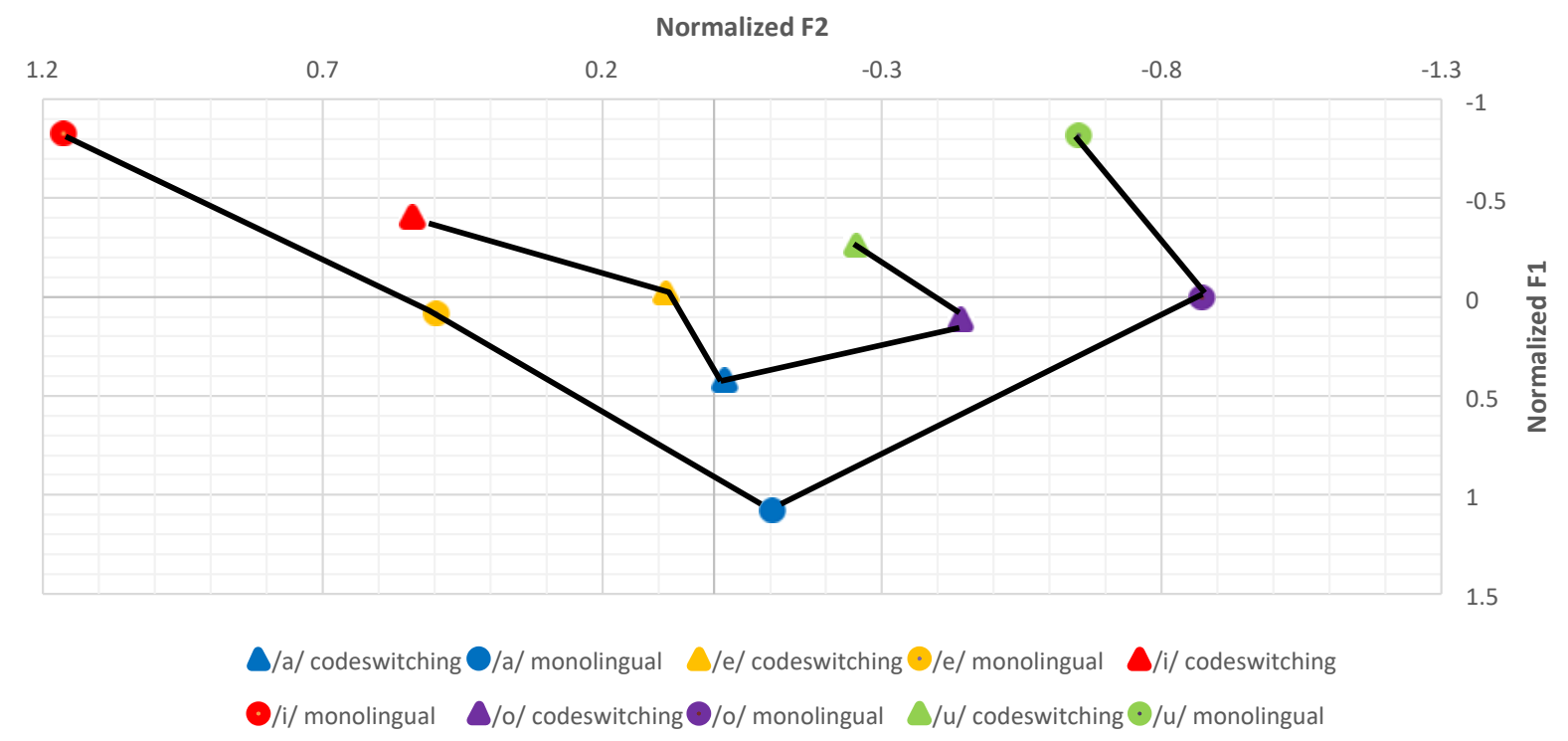

Figure 2. Vocalic triangle of monolingual (circles) and code-switching (triangles) vowels based on the averaged normalized F1 and F2 values.

The general trend that emerges from Figure 2 is that the monolingual session vowels occupy the outer space of the vowel chart, while the vowels in the code-switching session occupy the inner space. This is to say that although there were only statistically significant differences between $\mathrm{F} 1$ and F2 values and the type of session for two of the vowels (i.e., the high vowels $/ i$ / and $/ u /$ ), the other vowels had differences in either the F1 (i.e., /a/) or F2 values (i.e., the mid vowels /e/ and /o/) that moved the mean values of code-switching vowels to the inner space of the vowel chart.

A visual representation of the effect of lexical stress on normalized F1/F2 values is provided in Figure 3. In this figure, vowel tokens in lexically stressed syllables are represented by circles and vowel tokens in lexically unstressed syllables are represented by triangles. As with Figure 2, each vowel in Figure 3 is represented by its own color: blue $(/ \mathrm{a} /)$, yellow, $(/ \mathrm{e} /)$, red $(/ \mathrm{i} /)$, purple $(/ \mathrm{o} /)$, and green $(/ \mathrm{u} /)$. Normalized F1 values (i.e., vowel height) are found on the $y$-axis, while the normalized F2 values (i.e., front/backness) are on the $x$-axis; there is also a solid black line connecting the vowels to form the vocalic triangle. 


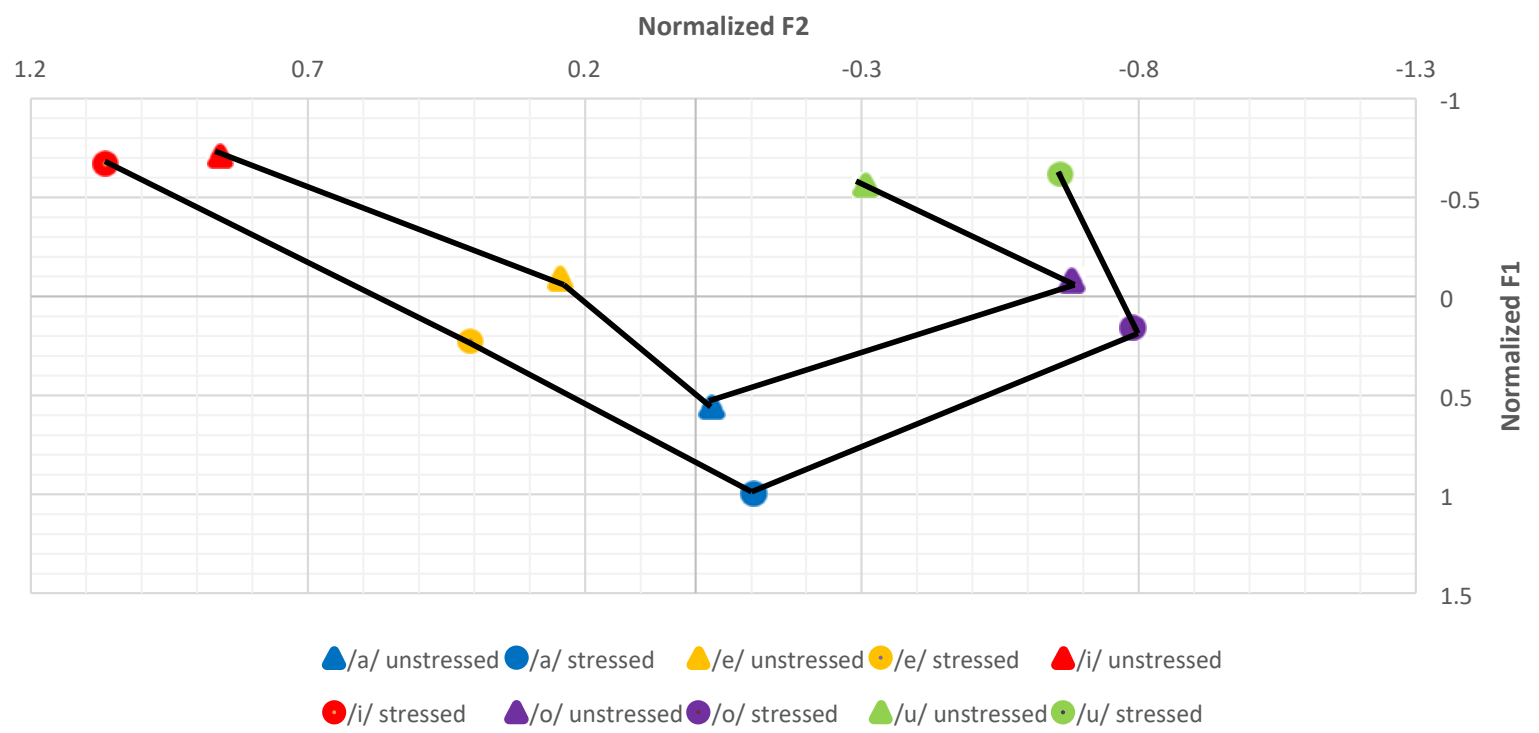

Figure 3. Vocalic triangle of stressed (circles) and unstressed (triangles) vowels based on the averaged normalized $F 1$ and $F 2$ values.

The general trend that emerges from Figure 3 is that vowel tokens in lexically stressed tokens are found in the outer space of the vowel chart, while vowel tokens in lexically unstressed syllables are found in the inner part of the vowel space. Although /o/ was the only vowel that showed statistically significant differences in F1 and F2 values between stressed and unstressed position, the other vowels did show movement to the inner vowel chart space either through statistically significant differences in F1 (i.e., /a/ and /e/) or F2 (i.e., /i/ and /u/).

With regard to the last dependent variable, vowel duration, given that its distribution was not normal (skewness $=1.48$, kurtosis $=4.51$ ), the raw values were submitted to log transformation to create a normal distribution (skewness $=-0.40$, kurtosis $=0.63$ ). For the log values of vowel duration there was a main effect for vowel phoneme, $F(4,3584)=77.93, p<0.001$, and lexical stress, $F(1,3587)=135.22, p<0.001$, but neither for language session, $F(1,3587)=0.71, p=0.40$, nor for DELE, $F(1,3587)=3.00, p=0.12$. There was a significant two-way interaction between vowel and lexical stress, $F(4,3584)=3.02, p=0.02$, but there were no significant interactions between vowel and language session, $F(4,3584)=1.98, p=0.10$, and between vowel phoneme, lexical stress, and language session, $F(1,3583)=1.74, p=0.12$.

To conclude this sub-section, the results from the linear mixed effects model in Tables 6 and 7 show that lexical stress, and not language session, affected the five Spanish vowels: vowels in unstressed position were shorter in duration than vowels in stressed position. There was no statistically significant main effect for language session.

Table 6. Descriptive results for vowel duration (ms).

\begin{tabular}{|c|c|c|c|c|c|}
\hline Interaction & Factors & $n$ & Mean (SD) & $95 \%$ CI & Effect Size $(d)$ \\
\hline \multirow{9}{*}{ Vowel and lexical stress } & Stressed /a/ & $\begin{array}{l}389 \\
560\end{array}$ & $\begin{array}{l}2.03(0.12) \\
1.96(0.15)\end{array}$ & {$[2.00,2.07]$} & \multirow[t]{2}{*}{0.52} \\
\hline & Unstressed /a/ & & & & \\
\hline & $\begin{array}{l}\text { Stressed /e/ } \\
\text { Unstressed /e/ }\end{array}$ & $\begin{array}{l}315 \\
480\end{array}$ & $\begin{array}{l}1.94(0.12) \\
1.90(0.15)\end{array}$ & $\begin{array}{l}{[1.90,1.97]} \\
{[1.86,1.93]}\end{array}$ & 0.29 \\
\hline & Stressed /i/ & 307 & $1.92(0.13)$ & {$[1.88,1.95]$} & \multirow{2}{*}{0.34} \\
\hline & Unstressed /i/ & 297 & $1.87(0.16)$ & {$[1.83,1.90]$} & \\
\hline & Stressed /o/ & 346 & $2.01(0.15)$ & {$[1.98,2.05]$} & \multirow{2}{*}{0.25} \\
\hline & Unstressed /o/ & 364 & $1.97(0.17)$ & {$[1.93,2.00]$} & \\
\hline & Stressed /u/ & 273 & $1.93(0.14)$ & {$[1.89,1.97]$} & \multirow{2}{*}{0.67} \\
\hline & Unstressed /u/ & 258 & $1.83(0.16)$ & {$[1.79,1.86]$} & \\
\hline
\end{tabular}


Table 6. Descriptive results for vowel duration (ms).

\begin{tabular}{|c|c|c|c|c|c|}
\hline Interaction & Factors & $n$ & Mean (SD) & $95 \% \mathrm{CI}$ & Effect Size $(d)$ \\
\hline \multirow{6}{*}{$\begin{array}{l}\text { Vowel and } \\
\text { language session }\end{array}$} & Code-switching / a/ & $\begin{array}{l}489 \\
460\end{array}$ & $1.99(0.14)$ & {$[1.95,2.02]$} & Pairwise difference (ns) \\
\hline & Code-cusitching / / / & 400 & $2.00(0.14)$ & {$[1$. [1, 2.04] } & \multirow[b]{2}{*}{ Pairwise difference (ns) } \\
\hline & Monolingual /e/ & $\begin{array}{l}364 \\
431\end{array}$ & $1.93(0.14)$ & {$[1.89,1.96]$} & \\
\hline & $\begin{array}{l}\text { Code-switching /i/ } \\
\text { Monolingual /i/ }\end{array}$ & $\begin{array}{l}194 \\
410\end{array}$ & $\begin{array}{l}1.89(0.12) \\
1.89(0.16)\end{array}$ & $\begin{array}{l}{[1.85,1.93]} \\
{[1.86,1.93]}\end{array}$ & Pairwise difference (ns) \\
\hline & $\begin{array}{l}\text { Code-switching /o/ } \\
\text { Monolingual /o/ }\end{array}$ & $\begin{array}{l}230 \\
480\end{array}$ & $\begin{array}{l}2.00(0.16) \\
1.98(0.17)\end{array}$ & $\begin{array}{l}{[1.96,2.04]} \\
{[1.94,2.01]}\end{array}$ & Pairwise difference (ns) \\
\hline & $\begin{array}{l}\text { Code-switching /u/ } \\
\text { Monolingual /u/ }\end{array}$ & $\begin{array}{l}218 \\
313\end{array}$ & $\begin{array}{l}1.87(0.16) \\
1.89(0.16)\end{array}$ & $\begin{array}{l}{[1.83,1.91]} \\
{[1.85,1.92]}\end{array}$ & Pairwise difference (ns) \\
\hline
\end{tabular}

Table 7. Results from the linear mixed effects model for vowel duration.

\begin{tabular}{|c|c|c|c|c|c|}
\hline Parameter & Estimate & SE & df & $t$-Value & $p$-Value \\
\hline Intercept & 2.09 & 0.09 & 9.40 & 22.46 & $<0.001$ \\
\hline Vowel = /a / & 0.11 & 0.02 & 1822.10 & 6.33 & $<0.001$ \\
\hline Vowel = /e/ & 0.02 & 0.02 & 890.51 & 1.10 & 0.27 \\
\hline Vowel = /i / & 0.00 & 0.02 & 1414.51 & 0.21 & 0.83 \\
\hline Vowel = /o/ & 0.06 & 0.02 & 1465.00 & 3.44 & 0.001 \\
\hline Lexical stress $=$ no & -0.09 & 0.02 & 1486.71 & -4.49 & $<0.001$ \\
\hline Language session $=$ code-switching & 0.00 & 0.10 & 2445.62 & -0.14 & 0.89 \\
\hline DELE scores & 0.00 & 0.00 & 8.98 & -1.73 & 0.12 \\
\hline Unstressed vowel = /a/ & 0.00 & 0.02 & 1838.52 & 0.38 & 0.71 \\
\hline Unstressed vowel $=/ \mathrm{e} /$ & 0.04 & 0.03 & 1268.93 & 1.40 & 0.16 \\
\hline Unstressed vowel $=/ \mathrm{i} /$ & 0.00 & 0.03 & 1632.94 & 0.30 & 0.76 \\
\hline Unstressed vowel = /o / & 0.06 & 0.02 & 1757.60 & 2.27 & 0.02 \\
\hline Code-switching vowel = /a / & -0.02 & 0.03 & 2719.57 & -0.642 & 0.52 \\
\hline Code-switching vowel = /e $/$ & -0.03 & 0.03 & 2083.54 & -0.98 & 0.33 \\
\hline Code-switching vowel = /i/ & -0.04 & 0.03 & 2380.31 & -1.28 & 0.20 \\
\hline Code-switching vowel $=/ \mathrm{o} /$ & 0.04 & 0.03 & 2342.13 & 1.63 & 0.10 \\
\hline Code-switching, unstressed vowel $=/ \mathrm{a} /$ & 0.01 & 0.02 & 3418.00 & 0.57 & 0.57 \\
\hline Code-switching, unstressed vowel $=/ \mathrm{e} /$ & 0.02 & 0.02 & 1918.86 & 0.80 & 0.42 \\
\hline Code-switching, unstressed vowel $=/ \mathrm{i} /$ & 0.06 & 0.03 & 2753.65 & 2.35 & 0.02 \\
\hline Code-switching, unstressed vowel $=/ \mathrm{o} /$ & -0.03 & 0.03 & 2516.14 & -1.32 & 0.17 \\
\hline Code-switching, unstressed vowel $=/ \mathrm{u} /$ & -0.03 & 0.03 & 2398.68 & -1.00 & 0.32 \\
\hline
\end{tabular}

\subsection{Distance from Code-Switching Site}

For the code-switching subset of the data, the F1 normalized results revealed that there was a main effect for vowel phoneme, $F(4,1491)=9.73, p<0.001$, lexical stress, $F(1,1494)=7.58, p<0.001$, but not for DELE, $F(1,1494)=1.20, p=0.30$, or distance from the code-switching site, $F(1,1494)=0.51$, $p=0.48$. Additionally, there were no significant two-way interactions between vowel and lexical stress, $F(4,1491)=1.99, p=0.10$, or between vowel and distance from the code-switching site, $F(1,1494)=0.99$, $p=0.41$.

With respect to the normalized F2 results, the linear mixed model indicated that there was a main effect for vowel phoneme, $F(4,1491)=5.51, p<0.001$, but not for lexical stress, $F(1,1494)=1.29, p=0.26$, DELE, $F(1,1494)=0.45, p=0.50$, or distance from the code-switching site, $F(1,1494)=0.76, p=0.38$. There were no significant two-way interactions between vowel and lexical stress, $F(4,1491)=1.48$, $p=0.21$, or between vowel and distance from the code-switching site, $F(1,1494)=2.05, p=0.09$.

Finally, the results for the log values of vowel duration show that there was a main effect for vowel phoneme, $F(4,1491)=16.04, p<0.001$, and for lexical stress, $F(1,1494)=54.77, p<0.001$, but not for DELE, $F(1,1494)=2.23, p=0.17$, or distance from the code-switching site, $F(1,1494)=2.57, p=0.11$. While there was a significant two-way interaction between vowel and lexical stress, $F(4,1491)=4.17$, 
$p=0.002$, there was not one between vowel and distance from the code-switching site, $F(1,1494)=0.69$, $p=0.60$.

\section{Discussion}

The present study set out to investigate the effects of code-switching and lexical stress on the vocalic production of 11 Midwest Spanish HSs, in addition to exploring the possible effect of distance from the code-switching site on these phonetic productions. We examined these questions through an experimental design that asked participants to read aloud children's stories that either contained English-Spanish code-switches (i.e., the code-switching session) or were only in Spanish (i.e., the monolingual session). These phonetic productions were then analyzed for vowel quality (i.e., normalized F1 and F2 values) and duration in order to quantify the extent of vocalic reduction.

The first research question asked, "is there an effect of code-switching and lexical stress on the vowel quality of heritage speakers of Spanish?" The results from various linear mixed effects models showed there were significant differences between the vowels in the code-switching and monolingual sessions with the normalized F1 (i.e., for /a/, /i/ and /u/) and normalized F2 (i.e., /e/, /i /, /o/ and $/ u /$ ) values. These differences between the monolingual and code-switching session were in the hypothesized direction, in that the vowels after a code-switch from English into Spanish were more centralized than their monolingual counterparts, as was visually shown in Figure 2; this is to say that even though there were not significant differences between both normalized F1 and F2 for all the vowels, there was at least one significant difference in either F1 or F2 that moved the vowels to the inner space of the vowel chart. In other words, the monolingual vowels all occupy a more outer space in the vowel chart, while the code-switching vowels occupy a more centralized space. Furthermore, it is also worth highlighting the fact that there is a large distance between all the monolingual vowels, while this distance appears to be reduced with the code-switching vowels.

The finding for the effect of code-switching on Spanish HS vowel production is consistent with previous research on Spanish-English code-switching, in which code-switching has been shown to affect Spanish voiceless stops [41,42]. In this pair of studies, the conflict site [59] between English and Spanish had to deal with differences in VOT, as English is traditionally classified as a language with long-lag VOT (i.e., more than $30 \mathrm{~ms}$ ), while Spanish is described as a short-lag VOT (i.e., between 0-30 ms) language [60]. In both Bullock and Toribio [40] and Piccinini and Arvaniti [42], the introduction of English via code-switching lengthened the VOT of Spanish voiceless stops. In the case of the present study, the conflict site between English and Spanish vowels has to do with the fact that Spanish vowel quality and duration is not affected by lexical stress, while there are differences in vowel quality and duration in English between tonic and atonic vowels [61]. The results of this study suggest that the introduction of English via code-switching produces statistically significant differences in the vowel quality between the two language sessions; this is to say, Spanish vowels after a code-switch from English into Spanish are influenced by the English that preceded them, provoking a change in their normalized F1 and/or F2 values.

Furthermore, our study adds empirical evidence to Simonet's hypothesis that transient interference should be more likely to occur in bilingual mode than in monolingual mode due to the activation of both languages in the bilingual speaker [39]. While Grosjean argues that it may be difficult to distinguish between interference and transfer [38], we concur with Simonet's assessment that within-speaker comparisons (i.e., between monolingual and bilingual mode) can be utilized to investigate transient effects [39]; furthermore, we would propose that comparisons between a bilingual speaker's productions in monolingual mode and productions from a monolingual speaker of that language would be a way to examine Grosjean's idea of transfer (i.e., permanent effects of one language on the other) [38]. Consequently, future research investigating transfer effects should compare the phonetic productions of monolingual Mexican Spanish speakers to those of HSs.

The second part of the first research question dealt with whether there were effects of lexical stress on Spanish vowel quality. The linear mixed effects models revealed that there were statistically 
significant differences between tonic and atonic vowels with the normalized F1 (i.e., for /a/, /e/, /o/) and normalized F2 (i.e., /i / , /o/ and / $/$ /) values. Similar to the results for language session, Figure 3 showed that the mean values for the tonic vowels are found on the outer edges of the vowel chart, while the mean values for the atonic vowels are found in the central space of the chart. This finding parallels the results from Ronquest [16], who also found significant differences in the vowel quality of Spanish HS stressed and unstressed vowels, even though the study was conducted entirely in Spanish. This is to say, the present study and Ronquest [16] both provide initial evidence that English may affect the Spanish HS vocalic system, although we concur with Ronquest [16] in noting that English may not be the sole explanation of the data in light of the fact that /e/ and /o/ in atonic position were slightly more raised than their tonic counterparts.

The second research question of the present study was concerned with the effect of code-switching and lexical stress on Spanish HS vowel duration. Our results show that lexical stress, and not code-switching, significantly affected vowel duration. More specifically, the results confirmed our hypothesized direction of influence, in that unstressed vowels were statistically shorter in duration than vowels in stressed syllables. Again, this result mirrors those found by Ronquest [16], as this study found significant differences for four of the five Spanish HS vowels in the same direction. The results from both of these studies point to a possible English influence on Spanish, given that unstressed vowels in English are quantitatively shorter in duration than vowels in stressed position.

With respect to the effect of the distance from the code-switching site and Spanish HS vowel quality (i.e., the third research question) and duration (i.e., the fourth research question), we did not find a statistically significant effect. While we concur with previous research [41] that distance from the code-switching site is a factor that should be examined with phonetic productions of bilinguals, our lack of evidence for its importance may be due to the fact that we limited the number of vowels taken after the code-switch to five. This is to say, it is possible that there was still a high level of activation from English during the production of these five vowels after the code-switch; future research should consider expanding the number of tokens taken after the code-switching site to see if there is a statistically significant effect of the distance from the code-switching site on normalized F1, normalized F2, and vowel duration values.

Overall, the present study has provided evidence that Spanish HS vowels may not be the same as their monolingual counterparts, which adds to the general HL research in this area [25-29,31]. However, without a comparison group of Mexican monolingual Spanish speakers from the same region as our participants' families, we can only claim that our HSs are different from what has been reported in descriptions of the Spanish language [34,35]. However, by comparing vowels from a monolingual session to vowels from the code-switching session, we are able to say that the introduction of a Spanish HS's other language influenced their vocalic productions. This finding concurs with the bilingual language modes framework [38] and Simonet's [39] empirical work, in that the activation of a language that reduces vowels (i.e., English), in terms of both vowel quality and duration, affected the productions of a language in which vowel reduction should not occur (i.e., Spanish).

While the present study has provided evidence that code-switching affects Spanish HS vowel production, as well as corroborating previous research [16] with respect to lexical stress, this study also raises some additional questions for future research. For example, the majority of the current research on Spanish HS phonetic production has employed experimental methods $[16,25-28,33,36,40,43,53,62,63]$ including the present study. Therefore, there is an open question about the role of task effect in these studies, as they might be different within more naturalistic contexts; future research should consider exploring Spanish HS phonetics with tasks that elicit more spontaneous data, such as sociolinguistic interviews.

\section{Conclusions}

With the purpose of increasing the body of research on Spanish HS phonetics, the present study explored whether the vocalic system of HSs of Spanish was influenced by the effects of code-switching 
between English and Spanish. Specifically, we aimed to investigate possible Spanish vocalic reduction of not only the language mode, but also those caused by the lexical stress and the distance from the code-switching site.

To answer these questions empirically, we obtained Spanish vowels from 11 Midwest Spanish HSs in a controlled reading task in both a monolingual and code-switching context. Our results show that code-switching had a significant effect on the vowel space of Spanish HSs, inasmuch as the linear mixed effects models revealed that there were statistically significant differences between vowels in code-switching and monolingual sessions, as well as differences between stressed and unstressed vowels; these differences were observed with the normalized F1 and/or F2 values, as well as with the duration of the vowel. The general trend that emerged from the present study is that both code-switching and unstressed syllables reduce the quality of Spanish HS vowels, via centralization, while unstressed syllables also shorten the duration of these vowels. Furthermore, we set out to investigate the potential role of distance from the code-switching site in affecting these vocalic productions, although we did not find any significant effects.

In summary, our study adds to the growing body of research of HL phonology $[25-29,31]$ that HSs may be different from their monolingual counterparts [25-29,31], and adds additional empirical evidence that comparisons between monolingual and bilingual modes can demonstrate transient interference of one language on another [39]. Furthermore, our study supports the trends found in previous research on Spanish HS vowels [16,30], as well as answering the call for more research to be conducted on Spanish HS phonology [14]. However, there is still much more work that should be conducted on the effect of Spanish-English code-switching on Spanish HS phonetic production, as well as the possible role of the distance from the code-switching site on these productions.

Acknowledgments: We would like to thank the audience participants of 5th Biennial Conference on Current Approaches to Spanish and Portuguese Second Language Phonology, the 8th International Workshop on Spanish Sociolinguistics and the 2nd International Conference on Bilingualism in the Hispanic and Lusophone World, as well as two anonymous reviewers and the Special Issue Editors for their comments on early presentations or drafts of this paper. We would also like to thank Rebecca Muth Ramsey of the Indiana University Center for Language Technology (Bloomington, IN, USA) for assistance with the audio recording, and Ru Wang of the Indiana Statistical Consulting Center (Bloomington, IN, USA) for assistance with the statistical analysis of the data. No funding was received for this study.

Author Contributions: All authors conceived and designed the experiment. (V.E.) recruited the participants and conducted the code-switching sessions and (A.M.M.) conducted the monolingual sessions. (S.M) and (A.M.M.) analyzed the data and (S.M.) conducted the statistical analyses. (V.E.) wrote the introduction and references, (A.M.M.) wrote the materials/methods and conclusion, (S.M) wrote the results and discussion sections and edited the paper.

Conflicts of Interest: The authors declare no conflict of interest.

\section{Appendix A. El Ratón de Ciudad y la Ardilla de Campo (The City Mouse and Country Squirrel)}

Había una vez un ratón de ciudad who went to visit an old friend, a squirrel, who lived in the country. La ardilla de campo era sencilla y bondadosa, y recibió con excitement the arrival of the city mouse. The squirrel tenía verduras, frijoles, nueces, y pan para ofrecerle a su amigo, pero se lo ofreció con generosidad. The city mouse, upon seeing this offering, made una cara de desprecio ante la comida que le ofrecía su amigo. Sin consideración ninguna the city mouse said to the squirrel:- No comprendo cómo puedes aguantar the backwardness of this country life. His friend couldn't believe that the squirrel would prefer the woods and fields to las calles llenas de carretas y de gente. I want you to return with me to the city donde vivo y te enseñaré cómo es mi vida en la ciudad. No country squirrel could refuse the invitation and together the two friends emprendieron el camino de vuelta a la ciudad esa misma tarde. On the way to the city, the country squirrel and city mouse met some culebras verdes. The friends se asustaron al verlas, but they soon realized que eran muy amables because they offered them some uvas para el viaje. The friends no pudieron creer lo tarde que era cuando entraron a la mansión where the city mouse lived. - Ya que hemos hecho un viaje tan largo, voy a ofrecerte something delicious to eat—said the mouse. Guided by el riquísimo banquete y su 
aroma, the two friends went to the great dining room. On an enormous table located in the middle of la habitación, encontraron los restos de una cena especial. The lavish table was set with cuchillos, cucharas y tenedores. Al instante, they were eating excelentes carnes, quesos selectos y sabrosas tartas. As the city mouse and country squirrel disfrutaban de las delicias, they didn't realize that un grupo de hombres y mujeres entered the room. The women were wearing bufandas con sus vestidos and the men had trajes azules.

Terrified, the two friends saltaron de la mesa y se precipitaron hacia el refugio más cercano. Llenos de miedo, se abrazaron fuertemente, hasta que no sentían the presence of the humans. But as soon as they left their place of refuge, they heard the bark of a dog que los condujo otra vez a su escondite. When the house finally calmed down, the country squirrel salió de la mansión that had given him such a fright, and wishing his friend a good life, he said: -It might be that you have a fondness for esta vida, pero yo prefiero nueces y frijoles en paz antes que pasteles y quesos con miedo.

\section{Appendix B. El Príncipe Pordiosero (The Beggar Prince)}

Este es el cuento del príncipe pordiosero. King Arnold had a beautiful daughter, whose name was Graciela. Al cumplir ella los veinte años, el rey invitó many neighboring princes to a party in honor of his daughter. Since she was unmarried, he wanted her to choose a husband. The princess was very rubia, dulce y cariñosa con todos. Ella tenía solamente un defecto: era indecisa. Rodeada por twelve suitors, she could not make up her mind and the king se enojó. Le gritó, "iJuro por Dios que te casaré con el primer hombre that enters this room!" At that exact moment, a beggar con ropa sucia, who had managed to avoid unos porteros, entró en la sala y exclamó, "Acabo de oír lo que dijo Ud.! ¡Juró por Dios! The princess is mine!" Since he could not go back on such a solemn oath, the king empezó los preparativos for the wedding de la Princesa Graciela. On the day of the wedding, everyone was surprised to see how handsome the beggar looked with ropa prestada. La gente decía que parecía ser príncipe al lado de la princesa. Al día siguiente, the new groom told the princess that they would have to start a new life. He had to return to his meager living and his humble house. They walked for three days until they came to a countryside que era muy verde y hermoso. Se escuchaba el cantar de pajarillos entre waterfalls, orchards and vineyards. At last, they arrived at a stone house que estaba construida al lado de un castillo. Frente a la casita, el nuevo esposo explicó that this was to be their new home. They lived there in poverty, but very happily, during el primer año. Una mañana, desde el jardín, Graciela vio pasar un magnífico caballero who was mounted on a splendid horse. When Graciela told her husband what she had seen, he said that it was probably Prince Philip and it appeared que la gente del valle lo admiraba mucho. Graciela ya no tenía las comodidades del palacio-ni joyas, ni sirvientas, ni cama. Sin embargo, she grew to love her husband and her simple life among las clases humildes del valle. Su esposo no ganaba mucho en el palacio así que un día he asked her if she could work alongside him at the palace that evening. Se dice que el Príncipe Felipe se ha casado y esta noche hay fiesta para la princesa who will be our new queen. I will leave for the palace now, and you can join me at eight. I'll be waiting inside la entrada principal. When Graciela arrived at the palace, se puso nerviosa y se sorprendió que los porteros bowed before her. She entered the hall, but could not see anything because the palace estaba oscuro. Suddenly she felt a big hug y escuchó una voz conocida. "Welcome to your palace, Princess Graciela, tonight's party se da en su honor. Soy el príncipe, el Príncipe Felipe, princesa."

\section{Appendix C. Cenicienta (Cinderella)}

Había una vez una joven muy bella whose mother had died when she was very young. Her father had remarried a widow que tenía dos hijas. Dentro de poco, él se arrepentió de haberse casado con such a cruel woman. With all of the suffering, él también murió, dejando a su hija con la impertinente mujer. The young girl was left to share the house with her ugly stepsisters que no querían hacer nada. Todo el día la joven hacía los quehaceres de la casa y como sus vestidos estaban siempre tan manchados de ceniza, la gente called her Cinderella. Un día el Príncipe de aquel país anunció que iba a dar una 
fiesta that would surpass them all. All the maidens in his kingdom would be invited. However, the cruel stepmother told Cinderella that she had to stay home and sweep el suelo y preparar la cena para cuando volvieran ella y sus feas hijas. Llegó el día del baile y con celos ella vio her stepsisters depart for the royal ball. Finally alone in the kitchen, Cenicienta no pudo reprimir las lágrimas. De repente, se le apareció su Hada Madrina. With her angelic voice, the Fairy Godmother consoled the crying girl. Después de descubrir el porqué de las lágrimas, the Fairy Godmother transformed her into a princesa con su varita mágica. She told the muchacha que podía ir al baile, but under one condition. When the Royal clock struck twelve, tendría que regresar a casa sin falta. La llegada de Cenicienta al Palacio caused a tremendous adulation. Al entrar en la sala de baile, the prince was so mesmerized by her belleza que bailó con ella toda la noche. Sus hermanastras didn't recognize her and they wondered quién era aquella joven. Because Cinderella was enjoying the ball so much, que no miraba la hora. Suddenly, she heard el reloj del Palacio dar las doce. Sin despedirse del príncipe, la joven ran from the great hall. She descended the stairs with tanta prisa que perdió una zapatilla which the Prince picked up with a glimmer of hope in his eyes.

\section{Appendix D. Blancanieves y los Siete Enanitos (Snow White and the Seven Dwarfs)}

In a country far far away, vivía una bella princesita llamada Blancanieves. Ella vivía con su madrastra who was very conceited and vain. Every day, la reina preguntaba a su espejo mágico quién era la más hermosa del reino, y cada día éste respondía: Tú eres, oh reina, la más hermosa de todas las mujeres. Fueron pasando los años. Un día la reina miró her magic mirror and asked who was the most beautiful in the kingdom. This time, however, the mirror answered: Snow White is the most beautiful. Entonces la reina, llena de ira y de envidia, mandó her servant, the hunter, to take Snow White to the forest and kill her. Como prueba de haber realizado el encargo, la reina le dijo que no regresara sin traerle el corazón de la princesa. Pero cuando llegaron al bosque el cazador sintió lástima de la joven inocente and didn't kill her, sustituyendo su corazón por él de un jabalí. Snow White, finding herself all alone, didn't know what to do, and began to cry. She spent toda la noche llorando y andando por el bosque hasta que, al amanecer, she arrived at a clearing in the woods and found una bella vivienda que se vio muy acogedora. She entered the house y no tenía miedo. Los muebles eran pequeñísimos y, había una mesa adornada con seven little plates and tiny silverware. She climbed up to la alcoba, que estaba ocupada por siete camitas. La pobre Blancanieves, agotada tras caminar toda la noche por el bosque, juntó all of the beds together and she fell right to sleep. Por la tarde llegaron los dueños de la casa: siete enanitos who had worked all day in the mines. They were surprised to find the young girl in their home, and with all the noise que hicieron, Blancanieves se despertó. Then she told them her triste historia. Los enanitos suplicaron a la niña que se quedara con ellos y Blancanieves aceptó. She stayed with her new friends and all were happy. Meanwhile, en el palacio, la reina asked the mirror again, who now was the most beautiful in the kingdom. The mirror respondió: - Sigue siendo Blancanieves, who now lives en el bosque rodeada de seven dwarfs. She couldn't believe her ears. Furious and full of rage, the cruel stepmother se disfrazó de inocente viejecita y partió hacia the little house in the woods.

\section{Appendix E. El Gato con Botas (Puss in Boots)}

Había una vez un molinero cuya única herencia para sus tres muchachos eran su molino, su burro y su gato. Pronto se hizo la repartición sin necesitar de un cura ni de un abogado, pues ya habían consumido todo el pobre patrimonio. Al mayor le tocó el molino, al segundo el burro, y al menor el gato que quedaba.

El pobre joven amigo estaba bien inconforme y asustado por haber recibido tan poquito.

"Mis hermanos"- dijo él, -"pueden hacer una bonita vida juntando sus bienes, pero por mi parte, después de haberme comido al gato, y hacer unas sandalias con su piel, entonces no me quedará más que morir de hambre." 
El gato, que escuchó todo eso, pero no lo tomaba así, le dijo en un tono firme y serio:

"No te preocupes tanto, mi buen dueño. Si me das un bolso, y un par de botas, con las que yo pueda atravesar lodos y zarzales, entonces verás que no eres tan pobre conmigo como te lo imaginas."

El dueño del gato no le dio mucha posibilidad a lo que le decía le dio el bolso y las botas y además un cuchillo. Sin embargo, a menudo lo había visto haciendo ingeniosos trucos para atrapar ratas y ratones, tal como colgarse por los talones, o escondiéndose dentro de los alimentos y fingiendo estar muerto. Así que tomó algo de esperanza de que él le podría ayudar a suavizar su miserable situación.

Después de recibir lo solicitado, el gato se puso sus botas caballerosamente, y amarró el bolso alrededor de su cuello. Se dirigió a un lugar donde abundaban los conejos, puso en el bolso un poco de cereal y de verduras, y tomó los cordones de cierre con sus patas delanteras, y se tiró en el suelo como si estuviera muerto. Entonces esperó que algunos conejitos, de esos que aún no saben de los engaños del mundo, llegaran a mirar dentro del bolso.

Apenas recién se había echado cuando obtuvo lo que quería. Un conejo tonto saltó a la bolsa, y el astuto gato, jaló inmediatamente los cordones cerrando la bolsa y capturando al conejo.

Orgulloso de su captura, fue al palacio del rey, y pidió hablar con su majestad. Él fue llevado arriba, a los apartamentos del rey, y haciendo una pequeña reverencia, le dijo:

“Majestad, le traigo a usted un conejo enviado por mi noble señor, el Marqués de Andalucía.

"Dile a tu dueño" dijo el rey, "que se lo agradezco mucho, y que estoy muy complacido con su regalo."

En otra ocasión fue a un campo de granos. De nuevo cargó de granos su bolso y lo mantuvo abierto hasta que un grupo de gallinas ingresaron, jaló las cuerdas y las capturó. Se presentó con ellas al rey, como había hecho antes con el conejo y se las ofreció. El rey, de igual manera recibió las gallinas con gran placer y le dio una propina dentro de una bufanda de seda. El gato continuó, de tiempo en tiempo, durante unos tres meses, llevándole presas a su majestad en nombre de su dueño.

Un día, en que él supo con certeza que el rey recorrería la ribera del río con su hija, la más encantadora princesa del mundo, le dijo a su dueño:

"Si sigues mi consejo, tu fortuna está lista. Todo lo que debes hacer es ir al río a bañarte en el lugar que te enseñaré, y déjame el resto a mí."

\section{References}

1. Beaudrie, S.; Fairclough, M. Spanish as a Heritage Language in the US: State of the Field; Georgetown University Press: Washington, DC, USA, 2012.

2. Dumitrescu, D.; Piña-Rosales, G. El Español en los Estados Unidos: E Pluribus Unum? Enfoques Multidisciplinarios; Academia Norteamericana de la Lengua Española: New York, NY, USA, 2013.

3. Pascual y Cabo, D. Advances in Spanish as a Heritage Language; John Benjamins Publishing Company: Philadelphia, PA, USA, 2016.

4. Potowski, K.; Rothman, J. Bilingual Youth: Spanish in English-Speaking Societies; John Benjamins Publishing Company: Amsterdam, The Netherlands, 2011.

5. Rivera-Mills, S.; Villa, D.J. Spanish of the U.S. Southwest: A Language in Transition; Iberoamericana: Madrid, Spain, 2010.

6. Roca, A. Spanish in the United States: Linguistic Issues and Challenges; Cascadilla Press: Somerville, MA, USA, 2000.

7. Roca, A.; Colombi, M.C. Mi Lengua: Spanish as a Heritage Language in the United States; Georgetown University Press: Washington, DC, USA, 2003.

8. Beaudrie, S. Research on university-based Spanish heritage language programs in the United States: The current state of affairs. In Spanish as a Heritage Language in the US: State of the Field; Beaudrie, S., Fairclough, M., Eds.; Georgetown University Press: Washington, DC, USA, 2012; pp. 203-221. 
9. Lynch, A. The first decade of the heritage Language Journal: A retrospective view of research on heritage languages. Heritage Lang. J. 2014, 11, 224-242.

10. Magaña, D. From pedagogy to communities: Issues within and beyond the Spanish heritage language classroom. Stud. Hisp. Lusoph. Linguist. 2015, 8, 375-388. [CrossRef]

11. Montrul, S. Current issues in heritage language acquisition. Annu. Rev. Appl. Linguist. 2010, 30, 3-23. [CrossRef]

12. Pascual y Cabo, D. Issues in Spanish heritage morphosyntax. Stud. Hisp. Lusoph. Linguist. 2015, 8, 389-401. [CrossRef]

13. Potowski, K. Heritage learners of Spanish. In Handbook of Second Language Spanish; Geeslin, K., Ed.; Wiley Blackwell: Hoboken, NJ, USA, 2013; pp. 404-422.

14. Rao, R.; Ronquest, R. The heritage Spanish phonetic/phonological system: Looking back and moving forward. Stud. Hisp. Lusoph. Linguist. 2015, 8, 403-414. [CrossRef]

15. Valdés, G.; Geoffrion-Vinci, M. Heritage language students: The case of Spanish. In The Handbook of Hispanic Sociolinguistics; Díaz-Campos, M., Ed.; Wiley Blackwell: Hoboken, NJ, USA, 2011; pp. 598-622.

16. Ronquest, R. An acoustic examination of unstressed vowel reduction in heritage Spanish. In Selected Proceedings of the 15th Hispanic Linguistics Symposium, University of Georgia, Athens, GA, USA, 6-9 October 2011; Howe, C., Blackwell, S., Lubbers Quesada, M., Eds.; Cascadilla Press: Somerville, MA, USA, 2013; pp. 151-171.

17. Valdés, G. AATSP Professional Development Series Handbook for Teachers K-16; Harcourt College Publishers: New York, NY, USA, 2000.

18. Montrul, S.; Foote, R.; Perpiñán, S. Gender agreement in adult second language learners and Spanish heritage speakers: The effects of age and context of acquisition. Lang. Learn. 2008, 58, 503-553. [CrossRef]

19. Pascual y Cabo, D.; Rothman, J. The (il)logical problem of heritage speaker bilingualism and incomplete acquisition. Appl. Linguist. 2012, 33, 450-455. [CrossRef]

20. Valdés, G. Bilingualism, heritage language learners, and SLA research: Opportunities lost or seized? Mod. Lang. J. 2005, 89, 410-426. [CrossRef]

21. Montrul, S. How native are heritage speakers? A look at gender agreement in Spanish. Heritage Lang. J. 2013, 10, 15-39.

22. Kupisch, T.; Lein, T.; Barton, D.; Schröder, D.J.; Stangen, I.; Stoehr, A. Acquisition outcomes across domains in adult simultaneous bilinguals with French as weaker and stronger language. J. Fr. Lang. Stud. 2014, 24, 1-30. [CrossRef]

23. Hualde, J.I. Los Sonidos del Español; Cambridge University Press: New York, NY, USA, 2014.

24. Alvord, S.; Rogers, B. Miami-Cuban Spanish vowels in contact. Sociol. Stud. 2014, 8, 139-170. [CrossRef]

25. Au, T.K.; Knightly, L.M.; Jun, S.A.; Oh, J. Overhearing a language during childhood. Psychol. Sci. 2002, 13, 238-243. [CrossRef] [PubMed]

26. Knightly, L.M.; Jun, S.A.; Oh, J.S.; Au, T.K. Production benefits of childhood overhearing. J. Acoust. Soc. Am. 2003, 114, 465-474. [CrossRef] [PubMed]

27. Au, T.K.; Oh, J.S.; Knightly, L.M.; Jun, S.A.; Romo, L. Salvaging a childhood language. J. Mem. Lang. 2008, 58, 998-1011. [CrossRef] [PubMed]

28. Oh, J.S.; Jun, S.A.; Knightly, L.M.; Au, T.K. Holding on to childhood language memory. Cognition 2003, 86, B53-B64. [CrossRef]

29. Hrycyna, M.; Lapinskaya, N.; Kochetov, A.; Nagy, N. VOT drift in 3 generations of heritage language speakers in Toronto. Can. Acoust. 2011, 39, 166-167.

30. Godson, L. Vowel production in the speech of Western Armenian heritage speakers'. Heritage Lang. J. 2004, 2, 1-26.

31. Saadah, E. The Production of Arabic Vowels by English L2 Learners and Heritage Speakers of Arabic. Ph.D. Thesis, University of Illinois at Urbana-Champaign, Urbana, IL, USA, 2011.

32. Chang, C.B.; Yao, Y.; Haynes, E.F.; Rhodes, R. Production of phonetic and phonological contrast by heritage speakers of Mandarin. J. Acoust. Soc. Am. 2011, 29, 3964-3980. [CrossRef] [PubMed]

33. Willis, E. An initial examination of Southwest Spanish vowels. Southwest J. Linguist. 2005, 24, $185-198$.

34. Quilis, A.; Esgueva, M. Realización de los fonemas vocálicos españoles en posición fonética normal. In Estudios de Fonética; Esgueva, M., Cantarero, M., Eds.; Consejo Superior de Investigaciones Científicas: Madrid, Spain, 1983; pp. 159-251. 
35. Gor, K. Raspberry, not a car: Context predictability and a phonological advantage in early and late learners' processing of speech in noise. Front. Psychol. 2014, 1449, 1-15. [CrossRef] [PubMed]

36. Lukyanchenko, A.; Gor, K. Perceptual correlates of phonological representations in heritage speakers and L2 learners. In Proceedings of the 35th Annual Boston University Conference on Language Development, Boston, MA, USA, 5-7 November 2010; Cascadilla Press: Somerville, MA, USA, 2011; pp. 414-426.

37. Silva-Corvalán, C. Language Contact and Change: Spanish in Los Angeles; Oxford University Press: New York, NY, USA, 1996.

38. Grosjean, F. An attempt to isolate, and then differentiate, transfer and interference. Int. J. Biling. 2011, 16, 11-21. [CrossRef]

39. Simonet, M. Phonetic consequences of dynamic cross-linguistic interference in proficient bilinguals. J. Phon. 2014, 43, 26-37. [CrossRef]

40. Bullock, B.E.; Toribio, A.J. Trying to hit a moving target: On the sociophonetics of code-switching. In Multidisciplinary Approaches to Code Switching; Isurin, L., Winford, D., de Bot, K., Eds.; John Benjamins Publishing Company: Amsterdam, The Netherlands, 2009; pp. 189-206.

41. Balukas, C.; Koops, C. Spanish-English bilingual voice onset time in spontaneous code-switching. Int. J. Biling. 2015, 19, 423-443. [CrossRef]

42. Piccinini, P.; Arvaniti, A. Voice onset time in Spanish-English spontaneous code-switching. J. Phon. 2015, 52, 121-137. [CrossRef]

43. Olson, D.J. The phonetics of insertional code-switching: Suprasegmental analysis and a case for hyper-articulation. Ling. Appl. Biling. 2012, 2, 439-457. [CrossRef]

44. Montrul, S. Second language acquisition and first language loss in adult early bilinguals: Exploring some differences and similarities. Second Lang. Res. 2005, 21, 199-249. [CrossRef]

45. Toribio, A.J. Spanish-English code-switching among US Latinos. Int. J. Sociol. Lang. 2003, 158, 89-119. [CrossRef]

46. Instituto Cervantes. Diploma de Español como Lengua Extranjera [Assessment Instrument]; Instituto Cervantes: Madrid, Spain, 2008.

47. Montrul, S. The Acquisition of Spanish: Morphosyntactic Development in Monolingual and Bilingual L1 Acquisition and Adult L2 Acquisition; John Benjamins Publishing Company: Amsterdam, The Netherlands, 2004.

48. Cuza, A.; Frank, J. Transfer effects at the syntax-semantics interface: The case of double-que questions in heritage Spanish. Heritage Lang. J. 2011, 8, 66-89.

49. Colantoni, L.; Cuza, A.; Mazzaro, N. Task-related effects in the prosody of Spanish heritage speakers and long-term immigrants. In Intonational Grammar in Ibero-Romance: Approaches Across Linguistic Subfields; Armstrong, M.E., Henriksen, N., Vanrell, M.M., Eds.; John Benjamins Publishing Company: Amsterdam, The Netherlands, 2016; pp. 3-24, ISBN 9789027267450.

50. Anderson, T.K. Spanish-English Bilinguals' Attitudes toward Codeswitching: Proficiency, Grammaticality and Familiarity. Ph.D. Thesis, Pennsylvania State University, State College, PA, USA, May 2006.

51. Saville-Troike, M. The Ethnography of Communication: An Introduction, 3rd ed.; Blackwell: Malden, MA, USA, 2003; ISBN 0631228411.

52. Torres Cacoullos, R.; Ferreira, F. Lexical frequency and voiced labiodental bilabial variation in New Mexican Spanish. Southwest J. Linguist. 2000, 19, 1-17.

53. Brown, E.; Harper, D. Phonological evidence of crosslinguistic exemplar connections. Stud. Hisp. Lusoph. Linguist. 2009, 2, 257-274.

54. Amengual, M. Interlingual influence in bilingual speech: Cognate status effect in a continuum of bilingualism. Biling. Lang. Cogn. 2012, 15, 517-530. [CrossRef]

55. Goldrick, M.; Runnqvist, E.; Costa, A. Language switching makes pronunciation less nativelike. Psychol. Sci. 2014, 25, 1031-1036. [CrossRef] [PubMed]

56. Lennes, M.; McCloy, D. Collect_formant_data_from_files.praat. Available online: https:/ /depts.washington. edu/phonlab/resources/getDurationPitchFormants.praat (accessed on 15 December 2016).

57. Lobanov, B.M. Classification of Russian vowels spoken by different speakers. J. Acoust. Soc. Am. 1971, 49, 606-608. [CrossRef]

58. Adank, P.; Smits, R.; Van Hout, R. A comparison of vowel normalization procedures for language variation research. J. Acoust. Soc. Am. 2004, 116, 3099-3107. [CrossRef] [PubMed] 
59. Poplack, S.; Meechan, M. How languages fit together in code-mixing. Int. J. Biling. 1998, 2, 127-138. [CrossRef]

60. Lisker, L.; Abramson, A.S. A cross-language study of voicing in initial stops: Acoustical measurements. Word 1964, 20, 384-422. [CrossRef]

61. Fletcher, J. The prosody of speech: Timing and rhythm. In Essential Clinical Skills: The Handbook of Phonetic Sciences, 2nd ed.; Hardcastle, W.J., Laver, J., Gibbon, F.E., Eds.; John Wiley \& Sons: Hoboken, NJ, USA, 2012; Volume 4, pp. 523-602.

62. Rao, R. On the status of the phoneme /b/ in heritage speakers of Spanish. Sintagma 2014, 26, 37-54.

63. Rao, R. Manifestations of /bdg/ in heritage speakers of Spanish. Heritage Lang. J. 2015, 12, 48-74.

2017 by the authors. Licensee MDPI, Basel, Switzerland. This article is an open access article distributed under the terms and conditions of the Creative Commons Attribution (CC BY) license (http://creativecommons.org/licenses/by/4.0/). 